\section{Nickel-Catalyzed Coupling of $\alpha$-Halocarbonyl Compounds with Arylboronic Acids}

Metal-Mediated Synthesis

Key words

$\alpha$-halocarbonyl compounds

arylation

arylboronic acids

nickel<smiles>[O+]c1ccccc1</smiles><smiles>[Y]C(=O)C([R])[R]</smiles>

\section{$\mathrm{Ni(}\left(\mathrm{PPh}_{3}\right)_{4}(5 \mathrm{~mol} \%), \mathrm{K}_{3} \mathrm{PO}_{4}$ (2 equiv)}<smiles></smiles>

up to $95 \%$ (2 equiv)

$\mathrm{R}^{1}=\mathrm{H}, 3-\mathrm{Me}, 4-\mathrm{Cl}, 4-\mathrm{Br}, 4-\mathrm{MeO}$ $\mathrm{R}^{2}=\mathrm{H}, \mathrm{Me}, n-\mathrm{Bu}, \mathrm{Ph}$ $\mathrm{R}^{3}=\mathrm{OEt}, \mathrm{Ni}-\mathrm{Pr}_{2}, \mathrm{NH}_{2}, \mathrm{Me}, \mathrm{Ph}$

$\mathrm{X}=\mathrm{Br}, \mathrm{Cl}$<smiles>CCOC(=O)Cc1ccccc1</smiles>

$93 \%$<smiles>NC(C(=O)N1CCCCC1)c1ccccc1</smiles>

$61 \%$

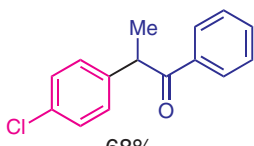

$68 \%$<smiles>CCOC(=O)C(c1ccccc1)[N+](=O)[O-]</smiles><smiles>CC(N)(C(N)=O)c1ccccc1</smiles>

$75 \%$

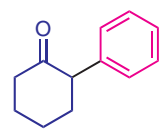

$75 \%(\mathrm{X}=\mathrm{Cl})$<smiles>CCOC(=O)C(CCBr)c1ccccc1</smiles>

$72 \%$<smiles>CCCCC(C(=O)OCC)c1ccc(Br)cc1</smiles>

$75 \%$

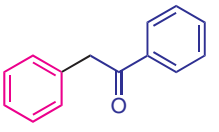

$63 \%(\mathrm{X}=\mathrm{Cl})$<smiles>O=C1OCCC1c1ccccc1</smiles>

$74 \%$<smiles>CCCCCNC(=O)C(C)c1ccc(Cl)cc1</smiles>

$90 \%$

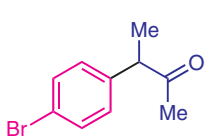

$60 \%(\mathrm{X}=\mathrm{Cl})$
Significance: $\alpha$-Arylated carbonyl compounds are important building blocks in the synthesis of biologically active substances. The catalytic arylation of enolates was so far the only general method of their synthesis. This is the first report of the direct catalytic coupling of $\alpha$-halocarbonyl compounds, including haloketones, with arylboronic acids. Chloro- and cyclic ketones give good yields of the arylated products. This reaction can also be quite useful for the synthesis of functionalized arylacetic acid derivatives, which are important industrial products.
Comment: G. C. Fu and co-workers reported the coupling of $\alpha$-halocarbonyl compounds with alkylzinc derivatives and $\mathrm{ArSiF}_{3}$ reagents, both using nickel catalysts (N. A. Stroman, S. Sommer, G. C. Fu Angew. Chem. Int. Ed. 2007, 46, 3655). In the presence of palladium, however, the main reaction under these conditions is the aryl homocoupling, in which the halocarbonyl compound serves as reoxidant for palladium. Due to the mild conditions, this method should possess a broader scope and functional group tolerability than the conventional arylation of enolates. 